\title{
MOTIVASI INTERNAL DAN EKSTERNAL PEMAKAIAN GIGI TIRUAN PADA PAGUYUBAN LANSIA "SEHAT BUGAR" POLTEKKES SEMARANG
}

\author{
Sukini $^{\varpi 1}$, Betty Saptiwi ${ }^{2}$, Wahyu Jati DU ${ }^{3}$, Endra Nastiti $D^{4}$
}

\begin{abstract}
ABSTRAK
Kerusakan gigi berupa karies apabila dibiarkan akan memberikan dampak pada kesehatan secara luas. Baik saat karies masih proses apalagi sudah tidak bisa dipertahankan dan harus dicabut. Kehilangan gigi dalam jangka waktu yang lama akan menyebabkan perubahan susunan gigi sehingga kontak menjadi tidak sempurna. Kehilangan gigi juga menyebabkan hal-hal negatif lainnya seperti berkurangnya fungsi berbicara dan fungsi estetika.

Meskipun sebagian besar orang memiliki gigi hilang baik oleh proses karies gigi maupun oleh sebab lain, tidak semuanya segera mencari gigi pengganti atau memakai gigi tiruan. Kesadaran untuk membuat gigi tiruan ini dipengaruhi oleh faktor motivasi baik internal maupun eksternal.Faktor internal diantaranya adalah persepsi diri, minat, kebutuhan dan harapan.Sedangkan faktor eksternal adalah dukungan dari keluarga, lingkungan, fasilitas pelayanan kesehatan, manfaat yang diterima dan imbalan.Motivasi adalah kekuatan yang mendorong atau menggerakkan seseorang untuk bertingkahlaku tertentu dan diarahkan pada suatu tujuan.

Jenis penelitian ini adalah observasionalcrossectional untuk mengetahui motivasi paguyuban lansia "Sehat Bugar"Poltekkes terhadap pemakaian gigi tiruan.Penelitian dilakukan pada akhir Agustus sampai awal November 2014.Data penelitian dilakukan pada bulan September 2014. Sampel yang digunakan adalah total atau keseluruhan yaitu 67 lansia dengan tujuan agar lebih mewakili hasil penelitian. Cara pengambilan skor adalah untuk pertanyaan negatif skor 0 jika jawaban ya dan untuk pertanyaan positif nilai 1 jika jawaban ya sebaliknya pertanyaan positif skor 1 jawaban ya dan o jika jawaban tidak.

Hasil Analisis Korelasi Chi Square Hubungan Antara Motivasi Internal dengan Pemakaian Gigi Tiruan menunjukkan bahwa ada hubungan yang signifikan antara motivasi internal dengan pemakaian gigi tiruan dengan nilai sig sebesar 0,012 ( $p<0,05)$.
\end{abstract}

Kata kunci : Motivasi internal, motivasi eksternal, pemakaian gigi tiruan

\begin{abstract}
Tooth damage like carries, even when the carries is still on process or when it cannot be maintained and should be removed, will cause some health problems if it is ignored. Loosing teeth in long term period will lead to the changes of teeth arrangement so the contact will be imperfect. Other negative impacts that are caused by caries are the decrease of speaking function and aesthetic functions.

Although most people loose their teeth, either by dental caries process or by other causes, not all of them immediately applying an artificial teeth or wear dentures. The awareness to make the denture is influenced by factors both internal and external. Internal factors include the self-perception, interests, needs and expectations. External factors consist of the support of family, environment, health care facilities, benefits and rewards received. Motivations is the factor that drives or moves a person to behave and lead towards a specific goal.

This research aims to observe the motivation of denture-using on Poltekkes Semarang's elders community "Sehat Bugar" Poltekkes. This observation research was conducted in the August until the early of September 2014, whereas the data were processed in September 2014. The sample used in this research is the total samples of 67 subjects in order to get a better representative.

The results of the Chi Square correlation analysis shows there is significant relationship between Internal motivation and the use of denture with $0.012(p<0.05)$ of sig value and there was no relationship between external motivation and the use of denture with 0.604 ( $p>0.05)$ of sig value.
\end{abstract}

Keywords : Internal motivation, External motivation, denture

\footnotetext{
$\overline{1,2,3,4)}$ Dosen Jurusan Keperawatan Gigi Poltekkes Kemenkes Semarang

$\bowtie$ : sukiyaki6707@yahoo.com
} 


\section{PENDAHULUAN}

Di dalam Undang-undang Kesehatan Republik Indonesia Nomor 36 tahun 2009 tentang Kesehatan menyebutkan pada pasal 93 bahwa pelayanan kesehatan gigi dan mulut dilakukan untuk memelihara dan meningkatkan derajad kesehatan masyarakat dalam bentuk peningkatan kesehatan gigi, pengobatan penyakit gigi dan pemulihan kesehatan gigi oleh pemerintah, pemerintah daerah dan atau masyarakat yang dilakukan dilakukan secara terpadu terintegrasi dan berkesinambungan (UU RI nomor 36, 2009).

Berdasarkan penelitian yang dilakukan oleh Sasmita dkk (2007), akibat dari kehilangan gigi terutama bila terjadi di bagian depan akan akan memperlihatkan wajah dengan bentuk bibir masuk ke dalam, sehingga dasar hidung. Kehilangan gigi juga dapat menimbulkan kesulitan dalam proses pengucapan beberapa huruf konsonan sehingga dapat dapat menyebabkan gangguan psikologis serta hilangnya kepercayaan diri.

Menurut Riskesdas 2013, prevalensi nasional masalah kesehatan gigi dan mulut adalah 25,9 persen. Secara keseluruhan kemampuan untuk mendapatkan pelayanan medis khususnya dari tenaga kesehatan gigi sebesar 8,1 persen. EMD (Exact Match Domain).EMD adalah data yang digunakan untuk mengukur nilai spesifikasi tertentu. Ditemukan EMD meningkat pada kelompok umur 45-54 tahun dari 10,6 dibanding umur 12 tahun yaitu 7,0. Kelompok usia 45 sampai 67 tahun mengalami kehilangan gigi sebanyak $25,3 \%$. Hilangnya gigi kelompok lanjut usia (selanjutnya disebut lansia) tersebut belum direspon oleh masyarakat dengan penggunaan gigi tiruan. Dari 25,3\% lansia yang kehilangan gigi baru $7.1 \%$ yang memakai gigi tiruan.

Dalam pengambilan keputusan untuk menggunakan gigi tiruan, faktor motivasi dapat memegang peranan yang sangat besar. Sebelum memutuskan menggunakan gigi tiruan sudah pasti setiap individu memiliki motivasi tertentu yang ia harapkan akan tercapai setelah penggunaan gigi tiruan tersebut (Nira, 2011). Menurut Cut Zurnali, (2004), motivasi adalah proses yang menjelaskan intensitas, arah, dan ketekunan seorang individu untuk mencapai tujuannya.

Paguyuban Lansia "Sehat Bugar" adalah kelompok lansia dibawah binaan Poltekkes Kemenkes Semarang. Dengan adanya informasi yang diberikan dari Poltekkes Semarang, kelompok ini diharapkan mempunyai persepsi yang lebih baik terhadap kesehatan dan akan merubah sikap kearah perilaku sehat termasuk dalam hal pemakaian gigi tiruan. Namun dari hasil pemantauan, khusus pada pemakaian gigi tiruan masih belum memenuhi harapan, semua anggota paguyuban belum memakai gigi tiruan (Data per Maret 2014).

Penelitian dilakukan untuk mengetahui motivasi internal dan eksternal pemakaian gigi tiruan pada Paguyuban Lansia "Segar Bugar" binaan Poltekkes Kemenkes Semarang.

\section{METODE PENELITIAN}

Jenis riset adalah analitik observasional dengan rancangan crossectional. Riset akan melakukan eksplorasi secara mendalam tentang motivasi internal dan eksternal pemakian gigi tiruan pada Paguyuban Lansia "Sehat Bugar" Politeknik Kesehatan Kemenkes Semarang.

Lokasi riset yaitu di Politeknik Kesehatan Kemenkes Semarang dan Perumahan P4A Pudak Payung pada akhir Agustus sampai Oktober 2014. Riset ini dilaksanakan pada bulan Agustus sampai dengan Oktober 2014. Paguyuban "Sehat Bugar" adalah kelompok lansia binaan Poltekkes Kemenkes Semarang sejak tahun 2012. Satu bulan sekali mereka didatangkan ke Poltekkes untuk mendapatkan bermacam kegiatan seperti senam, pemberian makanan tambahan, pemeriksaan gula darah, timbang berat badan, pengukuran tekanan darah, pengukuran asam urat serta pemeriksaan gigi dan mulut. Pada kesempatan ini periset 
bertemu untuk sosialisasi tentang riset yang akan dilakukan.

Variabel yang mempunyai hubungan dari uji korelasi kemudian secara bersamasama diuji dengan analisis Chi-square.

Pengambilan keputusan ada tidaknya pengaruh probabilitas yaitu :

a. Jika probabilitas $>0.05$ maka Ho diterima.

Artinya tidak ada pengaruh variabel bebas terhadap variabel terikat

b. Jika probabilitas < 0.05 maka Ho ditolak.

Yang berarti ada pengaruh antara variabel bebas terhadap variabel terikat.

\section{HASIL DAN PEMBAHASAN}

Paguyuban Lansia "Sehat Bugar" adalah kelompok lansia yang dibina oleh Politeknik Kesehatan Kemenkes Semarang sejak tahun 2012. Kegiatan lansia di Poltekkes Kemenkes Semarang diadakan setiap Jumat ke-3 pada pukul 06.30 sampai 08.30 dibawah koordinasi Unit Pelayanan dan Pengabdian Masyarakat (UPPM) Poltekkes. Bentuk kegiatan adalah senam bersama, pemberian makanan tambahan, informasi kesehatan / penyuluhan, pemeriksaan kesehatan berupa: timbang berat badan, mengukur tekanan darah, mengukur kadar asam urat, pemeriksaan kesehatan umum dan gigi.

Anggota Paguyuban Lansia "sehat Bugar" Poltekkes Semarang secara teratur mendapatkan pelayanan dan informasi kesehatan sehingga dengan adanya informasi yang diberikan, diharapkan kelompok ini mempunyai persepsi yang lebih baik terhadap kesehatan dan akan termotivasi merubah perilaku sehat termasuk dalam hal pemakaian gigi tiruan. Akan tetapi saat penelitian ini dilakukan ini semua anggota nya belum ada yang memakai gigi tiruan.

1. Motivasi Internal, Motivasi Eksternal dan Pemakaian Gigi Tiruan

Setelah kuesioner yang telah diisi lengkap oleh responden, dari 67 responden terkumpul kembali, dilakukan distribusi frekuensi responden terhadap jawaban tiap item pertanyaan sebagai berikut :

Tabel 1. Distribusi Frekuensi Motivasi Internal, Motivasi Eksternal dan Pemakaian Gigi Tiruan (N=67)

\begin{tabular}{|c|c|c|c|c|c|}
\hline No & Item & & $\mathrm{Ya}$ & & dak \\
\hline 1. & Motivasi Internal & $\mathrm{N}$ & $\%$ & $\mathrm{~N}$ & $\%$ \\
\hline A. & Persepsi diri & & & & \\
\hline 1. & 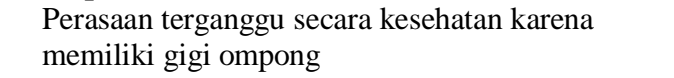 & 55 & 82,1 & 12 & 17,9 \\
\hline 2. & arena kehilangan gigi & 38 & 56,7 & 29 & 43,3 \\
\hline 3 & igi yang ompong bisa diatasi & 59 & 88,1 & 8 & 11,9 \\
\hline 4. & $\mathrm{k}$ dengan memakai gigi tiruan & 53 & 79,1 & 14 & 209 \\
\hline 5. & 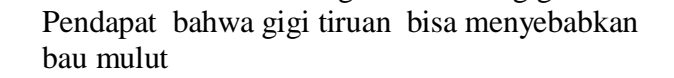 & 32 & 47,8 & 35 & 52,2 \\
\hline B. & Minat & & & & \\
\hline 1. & $\begin{array}{l}\text { Keinginan mengganti gigi yang ompong dengan } \\
\text { gigi tiruan }\end{array}$ & 50 & 74,6 & 17 & 25,4 \\
\hline 2. & an pencarian informasi tentang pembuatan & 29 & 43,3 & 38 & 56,7 \\
\hline 3. & $\begin{array}{l}\text { oahwa pemakaian gigi tiruan itu mudah } \\
\text { in }\end{array}$ & 30 & 44,8 & 37 & 55,2 \\
\hline 4. & $\begin{array}{l}\text { Keinginan membuat gigi tiruan karena kemauan } \\
\text { sendiri }\end{array}$ & 56 & 83,6 & 11 & 16,4 \\
\hline 5. & $\begin{array}{l}\text { Mempunyai kemampuan secara financial untuk } \\
\text { mengganti gigi yang ompong dengan gigi tiruan }\end{array}$ & 38 & 56,7 & 29 & 43,3 \\
\hline C. & Keb & & & & \\
\hline 1. & $\begin{array}{l}\text { Perasaan terganggu pengunyahannya karena ada } \\
\text { gigi yang hilang }\end{array}$ & 61 & 91,0 & 6 & 9,0 \\
\hline 2. & $\begin{array}{l}\text { Kebutuhan mengenai gigi tiruan untuk menunjang } \\
\text { aktifitas sehari-hari }\end{array}$ & 52 & 77,6 & 15 & 22,4 \\
\hline
\end{tabular}


$\begin{array}{lll}\text { No Item } & \text { Ya Tidak }\end{array}$

\begin{tabular}{llllll}
\hline 3. & Kebutuhan bahwa gigi tiruan ini termasuk sesuatu \\
yang bersifat mendesak & 29 & 43,3 & 38 & 56,7
\end{tabular} yang bersifat mendesak

4. Rela mengesampingkan kebutuhan sekunder demi $40 \quad 59,7 \quad 27 \quad 40,3$ pembuatan gigi tiruan

D. Harapan

1. Harapan bahwa dengan memakai gigi tiruan, seseorang bisa lebih baik daripada sebelumnya

2. Keyakinan bahwa dengan memakai gigi tiruan akan memperbaiki kualitas kehidupan di usia lansia

3. Keyakinan bahwa dengan memakai gigi tiruan akan bisa mengatasi hambatan yang muncul $61 \quad 91,0 \quad 6 \quad 9,0$ sebelum memakainya

4. Harapan adanya penghargaan dari orang lain saat memakai gigi tiruan

$43 \quad 64,2 \quad 24 \quad 35,8$

$\begin{array}{llll}55 & 82,1 & 12 & 17,9\end{array}$

2. Motivasi Eksternal

A. Dukungan Keluarga

1. Anggapan keluarga bahwa mempunyai gigi $51 \quad 76,1 \quad 16 \quad 23,9$ ompong adalah sesuatu yang wajar

2. Keluarga pernah memberikan informasi tentang $33 \quad 49,3 \quad 34 \quad 50,7$ gigi tiruan

3. Keluarga pernah menyarankan untuk membuat gigi $34 \quad 50,7 \quad 33 \quad 49,3$ tiruan

4. Keluarga mau membantu bila lansia kerepotan $42 \quad 62,7 \quad 25 \quad 37,3$ dalam proses pembuatan gigi tiruan

5. Keluarga akan merespon baik apabila lansia $47 \quad 70,1 \quad 20 \quad 29,9$ memakai gigi tiruan

6. Keinginan mendapat dorongan dari keluarga $48 \quad 71,6 \quad 19 \quad 28,4$ terhadap pemakaian gigi tiruan

B. Lingkungan

1. Kepedulian lingkungan dimana lansia tinggal $\begin{array}{lllll}58 & 86,6 & 9 & 13,4\end{array}$ terhadap kesehatan

2. Lingkungan komunitas lansia yang merespon dengan baik terhadap pemakaian gigi tiruan

$5176,1 \quad 16 \quad 23,9$

3. Lingkungan mempengaruhi keputusan lansia dalam menentukan pemakaian gigi tiruan

$31 \quad 46,3 \quad 36 \quad 53,7$

4. Orang yang tinggal di lingkungan lansia, sudah banyak yang memakai gigi tiruan

C. Fasilitasi Pelayanan Kesehatan

1. Memiliki kartu jaminan kesehatan

$\begin{array}{llll}37 & 55,2 & 30 & 44,8\end{array}$

2. Rutin memeriksakan kesehatan terutama gigi dan mulut

Fasilitas pelayanan kesehatan yang ada di lingkungan lansia sudah memberikan pelayanan yang cukup memadai terutama di bidang kesehatan gigi dan mulut

4. Lansia memanfaatkan dengan baik pelayanan kesehatan yang ada

$\begin{array}{llll}38 & 56,7 & 29 & 43,3\end{array}$

$\begin{array}{llll}37 & 55,2 & 30 & 44,8\end{array}$

Fasilitas pelayanan kesehatan yang biasa dikunjungi, cukup membantu memberikan informasi kesehatan terutama mengenai perlunya gigi tiruan

D. Manfaat yang diterima

1. Keyakinan diri dengan memakai gigi tiruan akan bermanfaat bagi kesehatan umum

2. Keyakinan diri bahwa dengan memakai gigi tiruan akan bermanfaat bagi kesehatan gigi dan mulut

3. Keyakinan diri akan menjadi lebih baik dalam pekerjaan, dengan memakai gigi tiruan

$\begin{array}{llll}49 & 73,1 & 18 & 26,9\end{array}$

4. Keyakinan diri bahwa akan lebih diterima di $\begin{array}{llllll}\text { masyarakat dan lingkungan keluarga dengan } & 49 & 73,1 & 18 & 26,9\end{array}$ memakai gigi tiruan 


\begin{tabular}{llllllll}
\hline No & \multicolumn{1}{c}{ Item } & Ya & \multicolumn{1}{c}{ Tidak } \\
\hline E. & Imbalan & & & & & \\
1. & $\begin{array}{l}\text { Perasaan bahwa repotnya memakai gigi tiruan } \\
\text { sepadan dengan manfaat yang diperoleh }\end{array}$ & 38 & 56,7 & 29 & 43,3 \\
2. $\begin{array}{l}\text { Perasaan bahwa biaya pembuatan gigi tiruan } \\
\text { sepadan dengan bahan dan manfaatnya }\end{array}$ & 54 & 80,6 & 13 & 19,4 \\
3. & $\begin{array}{l}\text { Pemakaian Gigi Tiruan } \\
\text { Pernah memakai gigi tiruan }\end{array}$ & 15 & 22,4 & 52 & 77,6 \\
\hline
\end{tabular}

Dari Tabel 1 di atas dapat dilihat hasil sebagai berikut :

1) Motivasi internal

a) Persepsi diri

Komponen persepsi diri lansia yang mendukung pemakaian gigi tiruan adalah pengetahuan bahwa gigi yang ompong bisa diatasi dengan gigi tiruan. Hal ini ditunjukkan dari persentase tertinggi jawaban responden yang mendukung pemakaian gigi tiruan ada pada pengetahuan tentang gigi ompong yang bias diatasi dengan memasang gigi tiruan, sebesar $88,1 \%$ (59 orang).

b) Minat

Komponen minat lansia yang mendukung pemakaian gigi tiruan adalah kemauan sendiri ingin membuat gigi tiruan. Hal ini ditunjukkan dari persentase tertinggi jawaban responden yang mendukung pemakaian gigi tiruan ada pada keinginan memakai gigi tiruan dikarenakan atas kemauan sendiri, sebesar 83,6\% (56 orang).

c) Kebutuhan

Komponen kebutuhan lansia yang mendukung pemakaian gigi tiruan adalah adanya perasaan terganggu pengunyahan makanan karena ada gigi yang hilang. Hal ini ditunjukkan dari persentase tertinggi jawaban responden yang mendukung pemakaian gigi tiruan ada pada adanya perasaan terganggu pengunyahan makanan karena ada gigi yang hilang, sebesar $91 \% \quad(61$ orang). d) Harapan

Komponen harapan lansia yang mendukung pemakaian gigi tiruan adalah kepercayaan bahwa dengan memakai gigi tiruan, akan bisa mengatasi hambatan yang muncul sebelum memakainya. Hal ini ditunjukkan dari persentase tertinggi jawaban responden yang mendukung pemakaian gigi tiruan ada pada kepercayaan bahwa dengan memakai gigi tiruan, akan bisa mengatasi hambatan yang muncul sebelum memakainya, sebesar $91 \% \quad(61$ orang).

2) Motivasi eksternal

a) Dukungan keluarga

Komponen dukungan keluarga lansia yang mendukung pemakaian gigi tiruan adalah adanya dorongan keluarga terhadap pemakaian gigi tiruan. Hal ini ditunjukkan dari persentase tertinggi jawaban responden yang mendukung pemakaian gigi tiruan ada pada keinginan lansia agar keluarga mendorong pemakaian gigi tiruan, sebesar $71,6 \%$ (48 orang).

b) Lingkungan

Komponen lingkungan lansia yang mendukung pemakaian gigi tiruan adalah kepedulian lingkungan tempat tinggal lansia terhadap kesehatan. Hal ini ditunjukkan dari persentase tertinggi jawaban responden yang mendukung pemakaian gigi tiruan ada pada adanya kepedulian lingkungan tempat tinggal lansia terhadap kesehatan, sebesar $86,6 \%$ (58 orang). 
c) Fasilitas pelayanan kesehatan

Komponen fasilitas pelayanan kesehatan lansia yang mendukung pemakaian gigi tiruan adalah adanya kepemilikan kartu jaminan kesehatan oleh lansia. Hal ini ditunjukkan dari persentase tertinggi jawaban responden yang mendukung pemakaian gigi tiruan bahwa lansia memiliki kartu jaminan, sebesar $86,6 \%$ (58 orang).

d) Manfaat yang diterima

Komponen manfaat yang diterima lansia yang mendukung pemakaian gigi tiruan adalah keyakinan bahwa dengan memakai gigi tiruan akan bermanfaat bagi kesehatan gigi dan mulut. Hal ini ditunjukkan dari persentase tertinggi jawaban responden yang mendukung pemakaian gigi tiruan ada pada keyakinan bahwa dengan memakai gigi tiruan akan berguna bagi kesehatan gigi dan mulut, sebesar $82,1 \%$ (55 orang).

e) Imbalan

Komponen imbalan yang diterima lansia yang mendukung pemakaian gigi tiruan adalah adanya perasaan bahwa biaya pembuatan gigi tiruan sepadan dengan bahan dan manfaatnya. Hal ini ditunjukkan dari persentase tertinggi jawaban responden yang mendukung pemakaian gigi tiruan ada pada perasaan bahwa biaya pembuatan gigi tiruan sepadan dengan bahan dan manfaatnya, sebesar $80,6 \% \quad(54$ orang).

3) Pernah Memakai Gigi Tiruan

Pada kuesioner ini pengalaman memakai gigi tiruan terdapat $22,4 \%$ (15 orang) sedangkan yang belum pernah memakai lebih banyak yaitu sebesar $77,6 \%$ (52 orang). Baik yang pernah memakai gigi tiruan maupun yang belum pernah, pada saat penelitian ini dilakukan keseluruhannya dalam keadaan tidak memakai gigi tiruan dengan satu alasan.

2. Distribusi Frekuensi Kategori Variabel Setelah dilakukan skoring, komponen tiap variabel dikategorikan menjadi 3 yaitu rendah, sedang dan tinggi, kemudian dibuat distribusi frekuensi. Tabel di bawah ini menunjukkan distribusi frekuensi mengenai motivasi internal baik tiap komponen maupun keseluruhan.

Tabel 2. Distribusi frekuensi kategori

\begin{tabular}{|c|c|c|c|}
\hline \multicolumn{4}{|c|}{ Motivasi Internal $(\mathrm{N}=67)$} \\
\hline Variabel & Kategori & $\begin{array}{l}\text { Frekuensi } \\
(\mathrm{N})\end{array}$ & $\begin{array}{c}\text { Persentase } \\
(\%)\end{array}$ \\
\hline \multirow{3}{*}{$\begin{array}{l}\text { Persepsi } \\
\text { diri }\end{array}$} & Rendah $(<1,7)$ & 7 & 10,4 \\
\hline & $\begin{array}{c}\text { Sedang }(1,7- \\
3,3)\end{array}$ & 19 & 28,4 \\
\hline & Tinggi $(>3,3)$ & 41 & 61,2 \\
\hline \multirow[t]{3}{*}{ Minat } & Rendah $(<1,7)$ & 14 & 20,9 \\
\hline & $\begin{array}{c}\text { Sedang }(1,7- \\
3,3)\end{array}$ & 22 & 32,8 \\
\hline & Tinggi $(>3,3)$ & 31 & 46,3 \\
\hline \multirow[t]{3}{*}{ Kebutuhan } & Rendah $(<1,3)$ & 6 & 9,0 \\
\hline & $\begin{array}{c}\text { Sedang }(1,3- \\
2,7)\end{array}$ & 24 & 35,8 \\
\hline & Tinggi $(>2,7)$ & 37 & 55,2 \\
\hline \multirow[t]{3}{*}{ Harapan } & $\operatorname{Rendah}(<1,3)$ & 9 & 13,4 \\
\hline & $\begin{array}{c}\text { Sedang }(1,3- \\
2,7)\end{array}$ & 12 & 17,9 \\
\hline & Tinggi $(>2,7)$ & 46 & 68,7 \\
\hline \multirow[t]{3}{*}{$\begin{array}{c}\text { Motivasi } \\
\text { Internal } \\
\end{array}$} & Rendah $(<6)$ & 11 & 16,4 \\
\hline & Sedang (6-12) & 10 & 14,9 \\
\hline & Tinggi $(>12)$ & 46 & 68,7 \\
\hline
\end{tabular}

Berdasarkan Tabel di atas dapat diketahui bahwa responden paling banyak berada pada kategori tinggi di komponen persepsi diri sebesar 46 orang $(68,7 \%)$, pada komponen minat sebesar 31 orang $(46,3 \%)$, pada komponen kebutuhan sebesar 37 orang $(55,2 \%)$ dan pada komponen harapan sebesar 46 orang $(68,7 \%)$.

Adapun distribusi frekuensi motivasi eksternal baik tiap komponen maupun secara keseluruhan, ditunjukkan pada Tabel berikut: 
Tabel 3. Distribusi frekuensi kategori Motivasi Eksternal $(\mathrm{N}=67)$

\begin{tabular}{|c|c|c|c|}
\hline Variabel & Kategori & $\begin{array}{c}\text { Frekuensi } \\
(\mathrm{N})\end{array}$ & $\begin{array}{c}\text { Persentase } \\
(\%)\end{array}$ \\
\hline \multirow[t]{3}{*}{$\begin{array}{c}\text { Dukungan } \\
\text { keluarga }\end{array}$} & Rendah $(<2)$ & 22 & 32,8 \\
\hline & Sedang (2-4) & 11 & 16,4 \\
\hline & Tinggi $(>4)$ & 34 & 50,7 \\
\hline \multirow[t]{3}{*}{ Lingkungan } & Rendah $(<1,3)$ & 10 & 14,9 \\
\hline & $\begin{array}{c}\text { Sedang }(1,3- \\
2,7)\end{array}$ & 20 & 29,9 \\
\hline & Tinggi $(>2,7)$ & 37 & 55,2 \\
\hline \multirow[t]{3}{*}{$\begin{array}{c}\text { Fasilitas pel } \\
\text { kes }\end{array}$} & Rendah $(<1,7)$ & 4 & 6,0 \\
\hline & $\begin{array}{c}\text { Sedang }(1,7- \\
3,3)\end{array}$ & 30 & 44,8 \\
\hline & Tinggi $(>3,3)$ & 33 & 49,3 \\
\hline \multirow[t]{3}{*}{ Manfaat } & Rendah $(<1,3)$ & 12 & 17,9 \\
\hline & $\begin{array}{c}\text { Sedang }(1,3- \\
2,7)\end{array}$ & 5 & 7,5 \\
\hline & Tinggi $(>2,7)$ & 50 & 74,6 \\
\hline \multirow[t]{3}{*}{ Imbalan } & Rendah $(<0,7)$ & 8 & 11,9 \\
\hline & $\begin{array}{c}\text { Sedang }(0,7- \\
1,3)\end{array}$ & 26 & 38,8 \\
\hline & Tinggi $(>1,3)$ & 33 & 49,3 \\
\hline \multirow[t]{3}{*}{$\begin{array}{l}\text { Motivasi } \\
\text { Eksternal }\end{array}$} & Rendah $(<7)$ & 2 & 3,0 \\
\hline & Sedang (7-14) & 35 & 52,2 \\
\hline & Tinggi (>14) & 30 & 44,8 \\
\hline
\end{tabular}

Berdasarkan Tabel 3, dapat dilihat bahwa responden pada semua komponen paling banyak berada pada kategori tinggi. Pada komponen dukungan keluarga sebesar 34 orang $(50,7 \%)$, pada komponen lingkungan sebesar 37 orang $(55,2 \%)$, pada komponen fasilitas pelayanan kesehatan sebesar 33 orang $(49,3 \%)$, pada komponen manfaat yang diterima sebesar 50 orang $(74,6 \%)$, dan pada komponen imbalan sebesar 33 orang $(49,3 \%)$.

Berdasarkan Tabel 3, juga diketahui bahwa skor total secara keseluruhan komponen motivasi eksternal dikategorikan, maka diperoleh responden paling banyak berada pada kategori sedang mengenai motivasi eksternal untuk melakukan pemakaian gigi tiruan sebesar 35 orang (44,8\%).

Sementara itu, distribusi frekuensi mengenai pemakaian gigi tiruan, dapat dilihat pada tabel berikut ini :
Tabel 4 : Distribusi Frekuensi Kategori Pemakaian Gigi Tiruan $(\mathrm{N}=67)$

\begin{tabular}{ccc}
\hline Kategori & Frekuensi (N) & Persentase \\
\hline Tidak & 52 & 77,6 \\
\hline Ya & 15 & 22,4 \\
\hline
\end{tabular}

Berdasarkan Tabel 4 diketahui bahwa sebagian responden yaitu sebesar 22,45 atau sebanyak 15 orang pernah memakai gigi tiruan sedangkan yang belum pernah memakai tidak sebanyak 52 orang $(77,6 \%)$ dan yang menggunakan gigi tiruan 15 orang $(22,4 \%)$. Keseluruhannya saat dilakukan penelitian tidak sedang memakai gigi tiruan.

3. Analisis Statistik

Rangkuman hasil analisis statistik bivariat dengan uji Chi-Square untuk menguji hubungan antara tiap komponen dalam motivasi internal dengan pemakaian gigi tiruan, dapat dilihat pada Tabel 5 berikut ini :

Tabel 5. Rangkuman Hasil Analisis Korelasi Chi Square Hubungan Antara Komponen

Motivasi Internal dengan Pemakaian Gigi Tiruan

\begin{tabular}{cccc}
\hline No & Variabel bebas & Variabel terikat & $\mathrm{P}$ value \\
\hline 1 & Persepsi diri & Pemakaian gigi tiruan & 0,061 \\
\hline 2 & Minat & Pemakaian gigi tiruan & 0,026 \\
\hline 3 & Kebutuhan & Pemakaian gigi tiruan & 0,073 \\
\hline 4 & Harapan & Pemakaian gigi tiruan & 0,154 \\
\hline
\end{tabular}

Berdasarkan Tabel 5 di atas menunjukkan bahwa ada sebanyak 1 komponen motivasi internal yang berhubungan secara signifikan dengan pemakaian gigi tiruan yaitu minat dengan nilai sebesar $0,026 \quad(\mathrm{p}<0,05)$. Sedangkan persepsi diri, kebutuhan dan harapan tidak berhubungan secara signifikan dengan pemakaian gigi tiruan. Jadi dapat disimpulkan bahwa pemakaian gigi tiruan ini lebih disebabkan oleh minat yang tinggi untuk menggunakan gigi tiruan dan tidak disebabkan oleh persepsi diri, kebutuhan dan harapan.

Adapun rangkuman hasil analisis statistik bivariat dengan uji Chi-Square untuk menguji hubungan antara tiap komponen 
dalam motivasi eksternal dengan pemakaian gigi tiruan, dapat dilihat pada Tabel 6 berikut ini :

Tabel 6. Rangkuman Hasil Analisis Korelasi Chi Square Hubungan Antara Komponen Motivasi Eksternal dengan Pemakaian Gigi Tiruan.

\begin{tabular}{cccc}
\hline No & Variabel bebas & Variabel terikat & P value \\
\hline 1 & Dukungan keluarga & $\begin{array}{c}\text { Pemakaian gigi } \\
\text { tiruan }\end{array}$ & 0,003 \\
\hline 2 & Lingkungan & $\begin{array}{c}\text { Pemakaian gigi } \\
\text { tiruan }\end{array}$ & 0,059 \\
\hline 3 & Fasilitas pel kes & $\begin{array}{c}\text { Pemakaian gigi } \\
\text { tiruan }\end{array}$ & 0,716 \\
\hline 4 & $\begin{array}{c}\text { Manfaat yang } \\
\text { diterima }\end{array}$ & $\begin{array}{c}\text { Pemakaian gigi } \\
\text { tiruan }\end{array}$ & 0,321 \\
\hline 5 & Imbalan & $\begin{array}{c}\text { Pemakaian gigi } \\
\text { tiruan }\end{array}$ & 0,713 \\
\hline
\end{tabular}

Berdasarkan Tabel-6 di atas menunjukkan bahwa ada sebanyak 1 komponen motivasi eksternal yang berhubungan secara signifikan dengan pemakaian gigi tiruan yaitu dukungan keluarga. Sedangkan lingkungan, fasilitas pelayanan kesehatan, manfaat yang diterima dan imbalan tidak berhubungan secara signifikan dengan pemakaian gigi tiruan. Adapun bila antara seluruh komponen motivasi internal dan pemakaian gigi tiruan dihubungkan akan diperoleh hasil ada hubungan yang signifikan antara motivasi internal dengan pemakaian gigi tiruan dengan nilai sig sebesar $0,012(\mathrm{p}<0,05)$.

Sedangkan bila antara seluruh komponen motivasi eksternal dan pemakaian gigi tiruan dihubungkan akan diperoleh tidak ada hubungan antara motivasi eksternal dengan pemakaian gigi tiruan dengan nilai sig sebesar 0,604 ( $p>0,05)$.

1. Motivasi Internal Lansia Di Paguyuban Lansia "Sehat Bugar" Poltekkes Kemenkes Semarang.

Tabel 1 menunjukkan bahwa kontribusi terbesar dari motivasi internal lansia terhadap pemakaian gigi tiruan ada pada perasaan terganggunya pengunyahan karena ada gigi yang hilang dan adanya kepercayaan bahwa dengan memakai gigi tiruan akan bisa mengatasi hambatan yang muncul sebelum memakai gigi tiruan. Misalnya sebelum memakai gigi tiruan tidak bisa makan makanan yang keras terutama pada kehilangan gigi geraham.

Peringkat kedua yang memberikan kontribusi besar adalah pengetahuan bahwa gigi yang ompong bisa diatasi dengan gigi tiruan. Kondisi ini memberi pencerahan akan adanya jalan keluar bagi masalah hilangnya gigi, ada harapan terhadap penyelesaian masalah hilangnya gigi yaitu dengan dipasang gigi baru berupa gigi tiruan yang mempunyai fungsi dan bentuk hamper sama dengan gigi asli. Peringkat ketiga adalah minat bahwa keinginan membuat gigi tiruan karena kemauan sendiri.Dengan adanya persepsi yang benar terhadap gigi tiruan maka minat untuk memakainya menjadi timbul.

Dari Tabel-2 dapat diketahui bahwa motivasi internal pemakaian gigi tiruan di paguyuban lansia "Sehat Bugar" Poltekkes Kemenkes Semarang termasuk dalam kategori tinggi. Bila dilihat dari tiap komponen dari motivasi internal meliputi persepsi diri, minat, kebutuhan dan harapan semua berada pada kategori tinggi. Gambaran ini menunjukkan bahwa pemakaian gigi tiruan di paguyuban lansia "Sehat Bugar" Poltekkes Kemenkes Semarang dikarenakan lansia mempunyai persepsi diri, minat, kebutuhan dan harapan yang tinggi terhadap pemakaian gigi tiruan.

2. Motivasi Eksternal Lansia di Paguyuban Lansia "Sehat Bugar" Poltekkes Kemenkes Semarang.

Tabel-1 menunjukkan bahwa kontribusi terbesar dari motivasi eksternal lansia terhadap pemakaian gigi tiruan ada pada adanya kepedulian lingkungan terhadap kesehatan dimana lansia tinggal.Orang memiliki kecenderungan mengikuti trend yang ada di lingkungannya. Pada lingkungan dimana banyak orang memakai gigi tiruan maka akan mudah bagi seseorang untuk mengikuti mode tersebut tanpa kawatir 
dianggap aneh atau tidak lazim di lingkungannya. Peringkat kedua yang memberikan kontribusi besar adalah pemanfaatan dengan baik pelayanan kesehatan yang ada.Kepercayaan pada tempat pelayanan kesehatan yang biasa dikunjungi mempengaruhi keputusan memakai gigi tiruan.

Peringkat ketiga adalah adanya keyakinan bahwa dengan memakai gigi tiruan akan bermanfaat bagi kesehatan gigi dan mulut. Kehilangan gigi mempengaruhi fungsi pengunyahan. Hilangnya gigi depan menyebabkan hambatan pada saat harus menggigit dan memotong makanan.

Dari Tabel 2 dapat diketahui bahwa motivasi eksternal pemakaian gigi tiruan di paguyuban lansia "Sehat Bugar" Poltekkes Kemenkes Semarang termasuk dalam kategori sedang.Bila dilihat dari tiap komponen dari motivasi eksternal meliputi dukungan keluarga, lingkungan, fasilitas pelayanan kesehatan, manfaat yang diterima dan imbalan, semua komponen berada pada kategori tinggi.

Gambaran ini menunjukkan bahwa pemakaian gigi tiruan di paguyuban lansia "Sehat Bugar" Poltekkes Kemenkes Semarang dikarenakan lansia mempunyai dukungan keluarga, lingkungan, fasilitas pelayanan kesehatan, manfaat yang diterima dan imbalan yang tinggi terhadap pemakaian gigi tiruan. Hal ini menggambarkan bahwa secara keseluruhan motivasi eksternal tidak begitu mempengaruhi pemakaian gigi tiruan pada anggota Paguyuban Lansia "Sehat Bugar" Poltekkes Kemenkes Semarang.

3. Hubungan Antara Motivasi Internal Dengan Pemakaian Gigi Tiruan

Tabel 5 menunjukkan bahwa ada hubungan yang signifikan antara motivasi internal dengan pemakaian gigi tiruan. Apabila dilihat hubungan tiap komponen motivasi internal menunjukkan bahwa ada hanya 1 komponen motivasi internal yang berhubungan secara signifikan dengan pemakaian gigi tiruan yaitu minat dengan nilai sebesar $0,026(\mathrm{p}<0,05)$.

Persepsi diri, kebutuhan dan harapan tidak berhubungan secara signifikan dengan pemakaian gigi tiruan. Jadi dapat disimpulkan bahwa pemakaian gigi tiruan hal ini menunjukkan bahwa komponen minat lebih besar pengaruhnya daripada komponen motivasi internal lain, sesuai dengan pendapat Taufik (2007) yang mengatakan bahwa minat bisa mendominasi motivasi seseorang, sehingga mengalahkan komponen motivasi yang lain.

4. Hubungan Antara Motivasi Eksternal Dengan Pemakaian Gigi Tiruan

Tabel 6 menunjukkan bahwa tidak ada hubungan yang signifikan antara motivasi eksternal dengan pemakaian gigi tiruan $(\mathrm{p}=0,604)$. Hal ini menunjukkan bahwa pemakaian gigi tiruan oleh anggota paguyuban lansia "Sehat Bugar" lebih banyak dipengaruhi oleh motivasi internal daripada motivasi ekternalnya. Sehingga perlu stimulan dan pendekatan untuk merubah keadaan tidak memakai menjadi memakai gigi tiruan.

Apabila dilihat berdasarkan hubungan tiap komponen motivasi eksternal menunjukkan bahwa hanya ada 1 komponen motivasi eksternal yang berhubungan secara signifikan dengan pemakaian gigi tiruan yaitu dukungan keluarga dengan nilai $\mathrm{p}$ sebesar 0,003 $(\mathrm{p}<0,05)$. Sehingga lingkungan, fasilitas pelayanan kesehatan, manfaat yang diterima dan imbalan tidak berhubungan dengan pemakaian gigi tiruan.Jadi dapat disimpulkan bahwa pemakaian gigi tiruan oleh lansia di paguyuban lansia "Sehat Bugar" Poltekkes Kemenkes Semarang, lebih disebabkan oleh dukungan keluarga yang tinggi untuk menggunakan gigi tiruan dan tidak disebabkan oleh lingkungan, fasilitas pelayanan kesehatan, manfaat yang diterima dan imbalan.Hal ini dimungkinkan karena pada dasarnya 
seorang lansia banyak bergantung pada keluarga, baik secara materiil maupun secara emosional.

\section{KESIMPULAN}

1. Motivasi internal lansia di paguyuban lansia "Sehat Bugar" Poltekkes Kemenkes Semarang termasuk dalam kategori tinggi dengan kontribusi terbesar ada pada perasaan terganggunya pengunyahan karena ada gigi yang hilang dan adanya kepercayaan bahwa akan bisa mengatasi hambatan yang muncul sebelum memakai gigi tiruan.

2. Motivasi eksternal lansia di paguyuban lansia "Sehat Bugar" Poltekkes Kemenkes Semarang termasuk dalam kategori tinggi dengan kontribusi terbesar adalah adanya kepedulian lingkungan terhadap kesehatan dimana lansia tinggal.

3. Ada hubungan yang signifikan antara motivasi internal dengan pemakaian gigi tiruan lansia di paguyuban lansia "Sehat Bugar" Poltekkes Kemenkes Semarang.

4. Tidak ada hubungan yang signifikan antara motivasi eksternal dengan pemakaian gigi tiruan lansia di paguyuban lansia "Sehat Bugar" Poltekkes Kemenkes Semarang.

\section{SARAN}

1. Diharapkan ada upaya yang sungguhsungguh dan terpadu antara Poltekkes selaku Pembina kegiatan paguyuban lansia "Sehat Bugar" ini dengan ketua ketua kelompok agar bisa dilaksanakankegiatan yang bisa memotivasi para anggota paguyuban untuk memekai gigi tiruan..

2. Hasil penelitian ini menunjukkan bahwa minat lansia untuk memakai gigi tiruan sangat dominan, ditambah dengan pengetahuan dan dukungan keluarga maka besar kemungkinan mereka mau didorong untuk memakai gigi tiruan.

3. Poltekkes Kemenkes Semarang selaku stakeholder diharapkan bisa membantu mempermudah akses pelayanan, misalnya dengan adanya klinik gigi pada Jurusan Keperawatan Gigi (JKG) bisa dimanfaatkan untuk terjalinnya kerjasama antara paguyuban bisa difasilitasi melalui kerjasama dengan dokter gigi keluarga yang ditunjuk oleh BPJS sehingga pembuatan gigi tiruan bisa lebih mudah dan biaya lebih ringan. Hal ini bisa disinergikan dengan kegiatan pengabdian masyarakat.

\section{DAFTAR PUSTAKA}

Arikunto, Suharsini, 1998, Prosedur Penelitian Suatu Pendekatan Praktek, Rineka Cipta, Jakarta

Azwar, S., 2003, Sikap Manusia, Teori dan Pengukuran, Pustaka Pelajar, Yogyakarta

Davis DM, Fiske J, Scott B, Radford DR. 2000, The emotional effects of tooth loss: a preliminary quantitative study. Br Dent J

Darmono, Martono, 1999, Geriatri, Balai Penerbit FK UI, Jakarta

Darmodjo, 2006, Buku Ajar: Geriatrik (Ilmu Kesehatan lansia, Balai Penerbit, Jakarta

Depertemen Kesehatan Republik Indonesia.Laporan Riset Kesehatan Dasar Nasional 2013. Jakarta: Badan Penelitian dan Pengembangan Kesehatan.

Depkes RI, Subdit Perkesmas, 1982,Perawatan Pada Lansia, Jakarta

Departemen Pendidikan Nasional, 2004 Kamus Besar Bahasa Indonesia, Balai Pustaka, Jakarta 
Djamarah, 2002, Teori Motivasi, edisi II PT. Bumi Aksara, Jakarta

Gunadi U, Margo A, Burhan G, 1991, Buku Ajar Ilmu Geligi Tiruan Sebagian Lepasan, Hipokrates, Jakarta

Haryanto AG, Margo A, Burhan LK, Suryatenggara F, Setiabudi, 2012.. Buku Ajar Gigi Geligi Tiruan Sebagian Lepasan Jilid 1. Jakarta: Hipokrates.

Hardywinoto, Setiabudhi, 1999, Panduan Gerontologi: Menjaga Keseimbangan Kualitas Hidup Pada Lansia, Gramedia Pustaka utama, Jakarta

Hidayat, R Dede, 2009, Ilmu Perilaku Manusia Pengantar Psikologi Untuk Tenaga Kesehatan, Trans Info Media, Jakarta

Kidd EMA, Bechal SS, 1992, Dasar-dasar Karies Penyakit dan Penanggulangannya, Cetakan ke 2, EGC, Jakarta

Natamiharja L, 2000, Status Dan Kebutuhan Pelayanan Kesehatan Gigi Lansia Di Kotamadya Medan. Jurnal Kedokteran Gigi Universitas Indonesia. [serial online]; [cited 24 april 2013]; 7 (1): [14-22]. Available from: URL: http:// repository.usu.ac.id/ bitstream/ 123456789 /7913 / 3/09E01533.pdf.txt

Republik Indonesia, Undang-undang Nomor 13 Tahun 1998: Kesejahteraan Lansia

Simon, H dan Yanae,RT, 2003, Technology for Implant Protheses. Int J Oral Maxilliofac Inpant

Supriyana, Fatimah, Betty. S, 2012, Motivasi Internal Dan Eksternal Ibu Balita Dalam Pemanfaatan Posyandu di Kelurahan Dadapsari Kecamatan
Semarang Utara Kota Semarang, Poltekkes Kemenkes Semarang

Wartawarga (2009) Konsep Motivasi Internal dan Eksternal, unpublished, http://wartawarga.gunadharma.ac.id 